\title{
PERFIS DOS PROFISSIONAIS DA INFORMAÇÃO E A SUA RELAÇÃO COM A LÍNGUA
}

\author{
Mário Pinto \\ Universidade Fernando Pessoa (Porto, Portugal)
}

Por se tratar de uma temática assaz abrangente, que contempla um vasto e heterogéneo leque de pontos de vista (não raro nos antípodas uns dos outros), envolve um não negligenciável universo de actores e, simultaneamente, requer algumas precauções - não só por versar sobre um domínio pouco consensual como também por ser consabido não apreciarem os jornalistas ser questionados por quem não pertence à classe ${ }^{1}$, o que comporta riscos - impõe-se que, ab initium, sejam identificados quer os pressupostos em que assenta esta reflexão quer os marcos que a delimitam.

Requisito cujo imperativo se torna tanto mais óbvio quanto, como na situação em apreço acontece, o tema proposto, não obstante lato, é, em simultâneo, duplamente redutor: primeiro, porque apesar de abrir as portas a um universo (rádio, televisão e imprensa) de tal amplitude, a verdade é que, por insusceptível de ser disseccionado no tempo e espaço disponibilizados, também obriga a opções; segundo, porque ao referir de forma explícita os profissionais da informação (a eles se circunscrevendo), exclui liminarmente os colaboradores (regulares e/ou eventuais), por norma autores de peças de assinalável rigor linguístico. Convém, por isso, que desde já esclareçamos cingir-se o trabalho ora apresentado à linguagem da imprensa ( $e$, daí, aos profissionais deste sector) por ser este o âmbito em que preferencialmente temos feito incidir o nosso estudo.

1. E este comentário de Martínez Albertos (1989, pp. 37-38) comprova: «Como periodista profesional [...] experimento que en muchas ocasiones se formulan contra los hombres de nuestra profesión acusaciones extremosas por parte de sectores que tienen una visión excesivamente purista y normativa de la lengua. Algunos académicos y algunos solemnes profesores de gramática han demostrado repetidamente que no son capaces de descubrir en los periódicos algo que resulte positivo por pequeño y mínimo que sea...», o que desde já esclarecemos não ser o nosso caso. 
Balizados os parâmetros entre os quais nos iremos mover e sublinhados os condicionalismos de uma reflexão que, porque pessoal, não estará isenta de subjectividade - no fundo, a inerente a toda e qualquer reflexão - potenciados por ser vasta a panóplia de prismas sob os quais a questão pode ser problematizada, passemos então à sua disquisição, não sem antes realçar o quanto nos preocupou que o ângulo de abordagem a adoptar fosse o mais judicioso e equânime possível.

E a primeira questão que se levanta (e urge esclarecer) é saber do que falamos quando falamos de perfis. Porque da clarificação deste conceito depende não só a definição da sua relação com a língua como também o prisma de abordagem a adoptar. $\mathrm{O}$ que não é de somenos, visto tratar-se de uma perspectiva - a forma como, de acordo com os seus perfis, os profissionais da informação se relacionam com a língua, a tratam/usam - que, fugindo ao comum, pode posicionar-se um tanto à margem do expectável. Imperativo de clarificação tanto mais pertinente quanto, dada a plurivocidade do vocábulo perfil, nós próprios chegámos a equacionar outras hipóteses de trabalho: desde algo similar ao conjunto de seis perfis de prestigiados jornalistas que o Diário de Notícias publicou ao longo de uma semana (de 15 a 20) de Agosto de $1999^{2}$, para nós confirmação de quão polissémico é o termo perfil, passando pela perspectiva ética/deontológica decorrente da sua acepção principal no dicionário ${ }^{3}$ - o que comportava o risco de, neste âmbito, termos de aludir a aspectos mais delicados, verbi gratia o próprio relacionamento entre jornalistas - à perspectivação do tema a partir da dicotomia ideológica esquerda/direita que, além de redutora, poderia equivaler a abrir a caixa de Pandora, fomentar discordâncias em nada consentâneas com este

2. Conjunto de trabalhos sobre jornalistas vedetas que leva Mário Mesquita (2003, pp. 43-44) a concluir pela existência de uma «apreciável variedade de perfis que traduzem o apelo de 'qualidades' muito distintas na apreciação dos profissionais do jornalismo.» 3. A saber: «2. Descrição nos traços mais pertinentes do carácter, da maneira de ser de uma pessoa. 4. Conjunto de aptidões e traços de personalidade de uma pessoa que a tornam indicada para o desempenho de determinado cargo ou função.», in Dicionário da Lingua Portuguesa Contemporânea, II, p. 2824. 
local de onde o que se espera/deseja é um profícuo intercâmbio de opiniões.

Excluídos, pelas razões invocadas, os ângulos de abordagem atrás ventilados, apresentemos então os prismas sob os quais nos propomos tratar o tema, e que são: as faixas etárias em que estes profissionais se inserem, a sua formação base, o estilo/género que tratam preferencialmente e a 'qualidade' da linguagem que usam - vertentes cujo denominador comum, por contraponto à prodigalidade existente noutros domínios, é a relativa escassez de bibliografia disponível, apodixe de ser o tratamento desta matéria quase tabu.

Comecemos, pois, pelo que mais curial nos parece: equacionar a questão da relação dos perfis dos profissionais da informação com a língua a partir das faixas etárias em que os mesmos se situam e das quais decorrem posturas senão diametralmente opostas, pelo menos muito diferenciadas (asserção que, como a seguir veremos, terá hoje de ser um tanto matizada por se estarem a esbater os seus contornos). De facto, e da atenta observação com que ao longo dos anos temos acompanhado o «fenómeno», é para nós inquestionável (apesar da reserva antes feita) existirem dois campos perfeitamente demarcados conforme se trate de profissionais de um escalão etário mais elevado ou de jovens em início de carreira (por vezes, já com alguns anos de actividade). Enquanto os primeiros (que estão na profissão por opção e "para ficar»), detentores de um saber de experiência feito, mantêm com a linguagem uma relação de respeito, quase culto (veneração) traduzido na utilização de uma construção frásica correcta (que inclui uma pontuação irrepreensível), um vocabulário adequado e sem erros ortográficos, os mais jovens - menos preparados, e, pior, não raro em trânsito pela profissão ${ }^{4}$ - não nutrem pela língua o respeito exigível, têm iniludíveis dificuldades em se exprimirem fluentemente, não dominam (por vezes, parece nem sequer conhecerem) as regras básicas da gramática sendo, por isso, os grandes responsáveis pelo depauperamento do idioma. Esta

4. Da qual fazem mero trampolim para outros voos, em particular políticos ('assessores de imprensa' num qualquer ministério ou secretaria de Estado), com prebendas que fazem corar o cidadão comum. 
é a nossa opinião, que com pesar registamos, e que esperamos não seja mal interpretada, porque se é, de facto, uma crítica, é construtiva: a de alguém que ainda acredita que o statu quo vai melhorar.

Acontece, contudo, que, problematizar deste modo a questão - como se de mero conflito de gerações se tratasse, pondo a tónica só na deficiente expressão da geração mais jovem de jornalistas - também não nos apraz particularmente, nem nos parece a via mais ortodoxa, não só por incorrer no risco de poder ser considerada o reafirmar de uma velha tese segundo a qual a língua falada ou escrita pelas novas gerações é sempre pior que a da anterior e quase a antecâmara do caos, como ainda pelo facto de exprobrá-las não constituir um incentivo à almejada melhoria, e, mormente, por, mesmo na «outra» geração, terem, nos últimos tempos (e são dados irrefutáveis obtidos no âmbito da pesquisa que conduzimos), começado a surgir inusitadas «excepções» - de que aduzimos uns quantos exemplos, todos eles de editoriais, portanto, de gente com responsabilidades acrescidas - que em nada a dignificam (e tornam imperioso que matizemos as asserções feitas no início desta rubrica), antes fazendo recear uma inconcebível regressão.

Domingo é dia de votar, e, independentemente de tudo o que tenhamos de fazer, há uma hora que temos de encontrar para colocar o nosso voto, porque é um dever cívico, é um acto de maturidade democrática e porque quem deliberadamente se abster fica sem legitimidade para «abrir a boca» e reclamar o que quer que seja.

O Primeiro de Janeiro, 8/6/2004, Editorial, p. 7, NM.

O sensacionalismo dos títulos, o apelo «voyeurista» das fotografias, já nada tem a ver com informação: é puro espectáculo.

Expresso, 10/6/2004, Editorial, p. 3, JAS.

E o essencial era, e é, saber que estratégias de desenvolvimento têm os consórcios concorrentes para a Galp. (...)

Mas sobra uma questão: a proposta da Carlyle seria, limpa dos argumentos e polémicas de natureza política, tão pior do que as escolhidas?

Diário Económico, 2/6/2004, Editorial, p. 36, MAF. 
Ao longo da vida proferiu algumas frases que se tronaram célebres. [...] Em 1994, quando lhe foi diagnosticada a doença de Alzheimer, escreveu ao povo americano: (...).

Diário de Notícias, 7/6/2004, Editorial, p. 5, s. a.

Se os números que se advinham se confirmarem à boca das urnas, fica provado que o problema existe, que tem de ser encarado de frente (...).

Jornal de Notícias, 6/6/2004, p. 9, JLP (Director de Redacção).

A pequena amostra reproduzida, intencionalmente circunscrita a editoriais e a jornais de referência ${ }^{5}$, é uma pálida ideia da panorâmica vigente e, em simultâneo, apodixe do retrocesso a que nos últimos tempos temos assistido. É, outrossim, per se paradigmática, porquanto corporiza alguns dos vícios hodiernamente mais recorrentes - divisão silábica na translineação, conjugações verbais e concordâncias - que, no entanto, não esgotam a pletora de anomalias com que amiúde somos confrontados.

Procurar aferir das determinantes do statu quo não se afigura, por motivos óbvios, tarefa de fácil consecução - talvez seja mesmo inexequível - embora nos inclinemos a crer que resultem da convergência de vários factores, nem todos igualmente ponderosos, mas em que pontifica a ausência de revisão.

Se é iniludível a falta de cuidado aquando da redacção - e seria estultícia pura tentar escamotear o óbvio: as frases de que está ausente a concordância interna, incongruentes, tautológicas, anfibológicas, não raro, inclusive, sem nexo, são a prova irrefragável de não ter sido efectuada a leitura do produto final - não menos evidente é a inexistência de revisão. Convicção que esteamos na inaudita quantidade de erros (ortográficos, de acentuação, de construção e inimagináveis gralhas) com que reiteradamente deparamos,

5. Diário de Notícias, Diário Económico (com um público-alvo muito específico), Expresso (com a agravante de, por ser um hebdomadário, nem sequer poder invocar como justificação a limitação temporal e, ademais, com a responsabilidade acrescida de ser, no género, o de maior tiragem), O Primeiro de Janeiro, por ser um dos periódicos mais antigos do país, e Jornal de Notícias, o diário de maior tiragem. 
mesmo onde era impensável existirem: nos antetítulos, títulos e subtítulos de alguns destes periódicos (mas a que nenhum está imune).

Analistas mantém previsões

Diário Económico, 2/6/2004, p. 11, LRR.

Portugal mantem apoio a António Vitorino

Jornal de Notícias, 15/6/2004, p. 5, s. a.

Têxtil e vestuário pode perder

30 milhões de trabalhadores

Jornal de Notícias, 15/6/2004, p. 25, APL.

Saddam diz estar com moral elevada

$\mathrm{O}$ antigo presidente iraquiano Saddam Hussein escreveu à família assegurando que está com a moral elevada, (...).

Saddam com moral elevada (legenda de foto)

Jornal de Notícias, 24/6/2004, p. 22, JMA.

O ministro diz querer

combater a «hiper-

-inflação de 'planos',

'comissões' e 'estudos'»

Expresso, 10/6/2004, p. 22, RPL.

O Hospital Santo António volta hoje a funcionar

em pleno, após um acordo entre a ARS-Norte e o

SIM, que permitiu a suspensão da greve que

durava desde 3 de Março e que afectou milagres

de utentes. Mas os médicos avisam que podem

voltar a paralizar.

O Primeiro de Janeiro, 4/5/2004, p. 4, LP.

José de Mello e Petrocer selecionados para a fase seguinte de negociações bilaterais com o Governo.

Diário Económico, 2/6/2004, p. 1 (manchete), FP. 
Apesar de só receber dois jogos neste Euro 2004, a cidade de Leiria está a recolher proventos do torneio. A capacidade hoteleira para este período está muito perto de estar esgotada e quem demandado até à cidade do Lis tem gostado.

O Primeiro de Janeiro, $14 / 6 / 2004$, p. 25 , s. a.

CRISE NA PJ $\triangleright$ PS, PCP e BE insistem na audição do director nacional por causa das demissões na Judiciária do Porto $D$ Declarações de Ataíde das Neves consideradas inopurtunas e graves Jornal de Notícias, 9/6/2004, p. 10, TL.

Drogas sintécticas estão

a aumentar brutalmente

Jornal de Notícias, 21/4/2004, p. 15, CV.

Precaridade económica, desemprego e

alcoolismo preocupam Guimarães

O Comércio do Porto, 28/2/2004, p. 18, RP.

Aversos

à novidade

Expresso, 13/3/2004, p. 1, EMPREGO,VA.

Desabamento desaloja idosa

O soalho cedeu com o estrondo e a senhora, de 78 anos, teve que dormir em casa de uma filha

O Comércio do Porto, 28/2/2004, p. 9, MP.

Suspeito de ter baleado mulher

com paradeiro desconhecido

Jornal de Notícias, 15/6/2004, p. 41, HS.

Trucidado

por comboio

ainda por

identificar

Jornal de Notícias, 9/5/2004, p. 42, NP. 
Daí que, não obstante cônscios dos riscos de emitir opiniões peremptórias, definitivas, mormente quando menos encomiásticas, não nos possamos coibir, perante tão frustrante panorâmica, de assinalar não serem as melhores as relações de certas franjas de profissionais da informação com a língua. E apesar de não estar ainda anunciado o divórcio, o litígio que o antecede já se instalou...

Ora, é justamente porque de forma recorrente confrontados com pletora de exemplos deste cariz que não podemos evitar de nos questionar quer sobre as consequências do postulado de Valbuena (os media impõem ao público a sua linguagem) quer sobre a pertinência do observado, com a proficiência que é seu apanágio, por Lázaro Carreter: será, de facto, o idioma um «magma viscoso, inestable, incierto», para certos profissionais que, por isso, se revelam ineptos para o moldar, com evidentes repercussões nos textos por si produzidos, e de que os leitores são as vítimas inermes?, vendo-nos assim forçados a reconhecer a razão dos críticos, assinalada por Bernardino Hernando (ibid., p. 15), que, depois de asseverar estar a linguagem doente, agonizante, postula: «(...) está enfermo, sobre todo, de 'periodismo' ya que son los Medios de Comunicación llamada social los que, por lo menos, agravan irresistiblement la enfermedad».

Polir a linguagem tendo em vista o incremento do nível cultural do público destinatário - mesmo sem veleidades de almejar o preconizado por Carmo Vaz (1992, p. 281): «Quando os jornalistas são grandes prosadores, a leitura do que escrevem dá prazer a quem lê, instrui, educa e ilumina a alma.» - é um imperativo que ganha foros de inadiável. Tanto mais que, dado estar em causa uma linguagem para um público, esta requer um tratamento especializado, na medida em que terá de satisfazer simultaneamente as exigências de descodificação de receptores muito diversos ${ }^{6}$.

Intimamente relacionado com o parâmetro a cuja disquisição acabámos de proceder e constituindo em simultâneo novo ângulo de abordagem, está este, que nos remete para outra questão reconhecidamente pouco pacífica: a da influência da formação

6. Cfr. M. Pilar Diezhandino, 1994, p. 25. 
de base dos profissionais da informação $0^{7}$ isto é, se detentores de licenciatura ou não e, no primeiro caso, se específica (em Ciências da Comunicação / Informação), afim ou da área das Ciências -, proveniência não negligenciável, porquanto, se os primeiros estão ipso facto habilitados para o exercício da profissão, o que, constituindo uma mais-valia lhes aumenta a responsabilidade, a legitimação dos outros advém de factores diversos, o que de modo algum pode indiciar menor propensão para o seu desempenho profissional (importa, a propósito, referir, que alguns dos expoentes máximos do jornalismo hodierno provêm justamente de outras áreas, em particular do Direito).

Paradoxalmente, no entanto, é na geração mais jovem, aquela cujos elementos são detentores de uma formação académica superior e específica (pelo que deveriam exprimir-se melhor), que surgem os maiores atropelos à expressão, o que nos leva a concluir que, não obstante os (profundos) conhecimentos técnicos que possuem, falham na redacção por não dominarem as regras da construção frásica, o que é por demais patente na estocástica distribuição dos complementos na oração - distribuição que constitui, aliás, o cerne do problema: ao optarem pela construção sintáctica psicológica (em lugar da lógica), o que até poderia ser salutar dadas as possibilidades que abre de enfatizar certos elementos (complementos) em detrimento de outros - sem concomitantemente observarem as regras de organização/hierarquização das componentes frásicas (as quais, dentro da liberdade de combinações que é própria do discurso, impõem limites), acabam por produzir constantes anfibologias, quando não frases puramente incongruentes ${ }^{8}$.

7. Designação que, de tão abrangente e heterogénea, merece a Mário Mesquita (2003, p. 44) este comentário «Artistas gráficos, médicos, polícias reformados, professores, padres, homens de negócios, literatos e tantos outros tipos convergiram para uma profissão que só no final do séc. XIX começou a definir com nitidez as fronteiras que demarcam o seu território».

8. Situação que em nossa opinião só tem paralelo, ainda que por razões bem diversas, nos textos dos profissionais provenientes da área da Economia, textos esses que, porque repletos de siglas (e, estas, com plural 'à inglesa', como verbi gratia em vip's), de anglicismos e de tecnicismos e contaminados sintacticamente e não só, são, amiúde, puramente ininteligíveis. 
Última perspectiva a equacionar, a abordagem do tema através do prisma dos estilos/géneros, per se determinante q. b. consabidas que são as especificidades inerentes a cada uma das suas variantes bem como as diferenças que lhes subjazem: verbi gratia, que é pelos seus traços formais e estruturais, decorrentes das técnicas utilizadas pelos jornalistas, e também pela maneira como interagem com os elementos paralinguísticos e não linguísticos que as enquadram, que as peças jornalísticas eminentemente informativas (já que o estilo das opinativas é livre) se distinguem de todas as outras (dos documentos burocráticos às literárias). Ou ainda, como também é sabido, que os diferentes jornais (e, neles, as múltiplas áreas de informação), por visarem públicos diferentes (e, dentro destes, diferentes sectores) e perseguirem distintas finalidades, admitem o uso de tipos de discurso diversos, mais ou menos coloquiais, mais ou menos cultos, mais ou menos técnicos, sendo mesmo desejável que a adequação do estilo ao tema dos textos varie consoante a natureza dos factos abordados. Do que resulta serem prioritariamente os destinatários das mensagens e o objectivo que se pretende alcançar (verbi gratia informar, explicar, persuadir), mas também o género jornalístico em que se trabalha, a determinar o estilo das peças jornalísticas.

Só que, enquanto nos aspectos formal e estrutural, a reportagem e a crónica apelam para a criatividade dos jornalistas, a notícia não se compadece com grandes desvios em relação ao modelo a que se subordina a sua estrutura externa. Pelo que, neste contexto, caberia à escrita jornalística tornar as mensagens informativas e explicativas (em especial as mais complexas e áridas) tão atraentes quanto possível, o que, lamentavelmente, nem sempre é observado: com efeito, se é no opinativo que, regra geral, encontramos os textos mais conseguidos (propiciadores de indizível fruição), foi no informativo (cuja responsabilidade é maior) que recolhemos os exemplos aqui aduzidos. O que não pode deixar de constituir intrigante paradoxo, na medida em que do atrás exposto deveria resultar maior responsabilização do informativo (porque da lavra de profissionais em exclusividade) e, por contraponto, 
maior tolerância para com o opinativo - onde pontificam os colaboradores, por norma pertencentes a outros universos (Direito e afins) e, como tal, não enquadráveis nos lídimos profissionais da informação (diferenciação que, como Baptista Bastos reconhece, quando assevera: «Sou só escritor. Colaboro nos jornais para ganhar a vida, para arredondar a conta ao fim do mês» $»^{9}$ o próprio Estatuto de Jornalista contempla ${ }^{10}$, pode radicar também na vertente económica).

Afloradas várias hipóteses e demonstrada a pluralidade de vertentes de abordagem possíveis na problematização do tema em apreço, detenhamo-nos agora na «qualidade» da linguagem usada e na forma como esta é ou não conseguida.

Sendo consensual que na imprensa se escreve para transmitir de forma imediatamente inteligível alguma coisa a alguém, «redigir bem» deveria ser o corolário lógico desta asseveração e o mínimo a exigir de um jornalista; acontece, porém - a julgar por opiniões (de maior ou menor peso) aqui e ali emitidas, muitas das quais vindas do seio da classe - não ser a melhor a relação de alguns destes profissionais com a língua. Pelo menos é o que assevera J. A. Saraiva, director do Expresso (2003, p. 73), que, citando o seu antecessor no cargo e referindo-se aos homens da casa diz, sem rodeios: «Está a ver como estes jornalistas escrevem mal?» ${ }^{11}$. Não menos cáustica é a opinião de Pedro Rolo Duarte ${ }^{12}$ que, depois de criticar a linguagem de $O$ Independente - sublinhando não ser fácil fazer um jornal deste género por não ser «qualquer um que

9. Em resposta à pergunta «Neste momento vê-se mais como escritor ou como jornalista?», formulada por Maria Teresa Horta numa entrevista que ele lhe concedeu; in DN, 10/11/2000, p. 50 .

10. «São considerados jornalistas aqueles que, como ocupação principal, permanente e remunerada, exercem funções de pesquisa, recolha, selecção e tratamento de factos, notícias ou opiniões, através de texto, imagem ou som, destinados a divulgação informativa pela imprensa, por agência noticiosa, pela rádio, pela televisão ou por outra forma de difusão electrónica», lei promulgada em 5/1/1999.

11. Mais adiante (id., p. 99), também a revisão é posta em causa: «(...) tinha a suspeita de que a revisão estava a trabalhar muito mal e fiz isso para os experimentar. Infelizmente, verifiquei que era verdade.»

12. Cf. «Considerações sobre os Indígenas», in O Independente, 27/9/1996, Vida, n. ${ }^{\circ}$ 437, pp. 50-51. 
escreve $e^{13}$, pontua e titula» à maneira deste semanário -, exprobra ainda outros vícios (tais como o abuso do trocadilho e o facto de utilizarem «o estrangeiro como língua mãe») e conclui competir ao director criar «(...) se acaso o repórter não tiver esse cuidado, frases ou parágrafos incompreensíveis ou aparentemente absurdos que deixem o leitor na dúvida: que quererão dizer com isto?». Posturas que temos dificuldade em compreender, tantos são os exemplos daqueles que, pela positiva, insistem em identificar jornalismo com correcção na escrita. É, entre muitos outros, o caso de Orlando Raimundo (1994, p. 9), que sublinha, «Fazer jornalismo é sobretudo escrever, e bem.», afirmação corroborada por Pilar Diezhandino (1994, p. 25), para quem «(..) escribir bien, de manera precisa y clara, es necesario, imprescindible, pero no suficiente.», o que reforça mais adiante (ibid., p. 186), citando Baroja: «(...) lo que se necesita es exactitud y claridad». Também Núñez Ladevéze (1979, p. 76) - apesar de conferir primazia ao acto de informar propriamente dito («El periodista es, pues, ante todo, un profesional que informa y no un redactor que escribe.») - afirma constituir o «redigir bem» um dos requisitos imprescindíveis do periodista.

É claro que a questão - pouco pacífica, como estes testemunhos demonstram - se complica mais quando, com toda a clareza, se pretende definir em que consiste «escrever bem». E isto por a noção ter evoluido rapidamente ao ritmo das mutações ocorridas nos últimos anos em todos os quadrantes. Basta, a propósito, recordar como ainda nos anos setenta do século passado prevalecia o conceito de que escrever bem era fazê-lo à maneira dos literatos, o que tanto fomentou a imitação - orgulhosamente ostentada - do estilo camiliano ou do queirosiano, enquanto hoje, como assinala Salvato Trigo (1987, pp. 12-13): «(...) o jornalismo feito entre nós cura ao máximo de evitar confundir-se com a literatura.» ${ }^{14}$

13. O que exemplifica: "Não se pode redigir "O eng. Guterres tem um projecto que acaba com as escolas primárias"; deve redigir-se "O eng. Guterres tem um projecto explosivo nas mãos. Que acaba com as escolas primárias. O ministro da tutela está furibundo. Marcelo já tem resposta. Que não é nada meiga"».

14. Quando, acrescenta o autor, ainda num passado não muito distante: «(...) essa distinção de fronteiras não era tão nítida, [...]. A crónica e o folhetim, e mais tarde a 
Ora, sem que se exija (ou sequer se estabeleça) como horizonte a consecução de tão supino desiderato, é óbvio emergir do atrás referido ser o domínio da língua hodiernamente reputado um requisito incontornável do profissional da informação; que, no entanto, não esgota todos os predicados que lhe são exigíveis. Ainda que continuando plenamente actual o postulado de Hemingway («frases curtas e verbos indicativos, sempre na voz activa utilizando uma linguagem simples e pela positiva»), outras questões ganham pertinência e acuidade. Tais como, ao nível da escrita, o imperativo de o jornalista eliminar os obstáculos à leitura, o primeiro dos quais radica no vocabulário usado. E isto porque, sendo seu objectivo veicular informação, o que passa, inexoravelmente, por ser compreendido por aqueles que o lêem, um dos aspectos que não pode descurar ao elaborar o seu texto, porque crucial, é a selecção vocabular. Com efeito, se, quando escreve, o jornalista tem à sua disposição, para traduzir com exactidão o pensamento, séries de palavras que lhe acodem ao espírito, nada legitima que não proceda à sua criteriosa triagem. Aliás, no que à imprescindibilidade desta selecção concerne, é tão elucidativa a asserção de Baptista Bastos, «É interessante a descoberta da palavra exacta, a frase bem lançada ${ }^{15}$ quão peremptório Rodrigues Lapa $(1979$, p. 23) ao postular repousar a arte de escrever «(..) essencialmente na escolha do termo justo para a expressão das nossas ideias e dos nossos sentimentos», ou seja, segundo o autor «(...) só escreveremos bem, quando, na série sinonímica, escolhermos a palavra ou o grupo de palavras que melhor se ajustam àquilo que queremos exprimir».

grande reportagem, aparecem-nos, assim, como espécies discursivas mistas pertencendo, a um tempo, ao jornalismo, pela sua quotidianidade, e à literatura, pelo imaginário que as acompanha. O jornalismo de língua portuguesa tem exemplos sobejos desses, digamos, jornalistas-escritores. Praticamente todos os nossos grandes escritores oitocentistas estiveram ligados ao jornalismo, sentindo-se no seu estilo vestígios desse quotidianismo informativo, da observação ligeira dos ambientes, da linguagem da transparência entregando-se à descodificação suave e imediata, como é o caso, entre outros, de Garrett nas suas Viagens. Mais próximo de nós, poderíamos lembrar um escritor para quem o jornalismo foi, de facto, uma autêntica escola literária bem visível, aliás, no seu estilo descritivo: referimo-nos a Raul Brandão.»

15. Em entrevista dada a Maria Teresa Horta, in Diário de Notícias, 10/11/2000, p. 50. 
Triagem que, como é óbvio, não foi efectuada nos exemplos que se seguem:

E embora as vítimas da queda do Cessna sob Camarate, em 4 de Dezembro de 1980, não fossem candidatos nas eleições presidenciais (...).

Expresso, 10/6/2004, p. 3, MAM.

António Guterres, então inquilino de São Bento, pedia contenção e queixava-se da «campanha negativa» da oposição... do PSD e do CDS. Hoje, juntos no Governo e na aliança Força Portugal, queixam-se do mesmo...

Diário de Notícias, 7/6/2004, p. 10, NS.

O crescimento da importância relativa desta categoria poderá ainda indicar que as campanhas de redução de danos estão a surgir algum efeito junto dos toxicodependentes.

Diário de Notícias, 7/6/2004, p. 41, ECS.

Mau estar na PJ

A conferência de imprensa de ontem (uma situação inédita na PJ do Porto) causou evidente mau estar na instituição.

Jornal de Notícias, $8 / 6 / 2004$, p. 7 , s. a.

No deve e haver da votação para as eleições europeias, registe-se que Portugal ficou manchado de rosa, da vitória do PS. A coligação Força Portugal apenas conseguiu pintar de laranja e azul os distritos de Viseu (...).

Diário de Notícias, 14/6/2004, p. 3, NS.

Sob o fundo de um canto glorificando a «jihad», os dois atiradores inclinam-se depois sobre o corpo da vítima para aparentemente lhe cortarem a cabeça. [...]

A cadeia de televisão Al-Jazeera mostrou o vídeo ontem, omitindo a parte em que os dois atacantes parecem decepar o cadáver.

Diário de Notícias, 14/6/2004, p. 3, NS. 
Ilação imediata a retirar destes exemplos - apodixe de como a rigorosa utilização das palavras é uma questão fulcral - é quão perniciosas terão sido as consequências do emprego incorrecto destes vocábulos, consabido que é poder a ininteligibilidade de certas asserções redundar no quiproquó, o que por vezes é pior e mais perigoso do que não ser entendido. É claro que esta exigência de rigor pressupõe a prévia verificação de um requisito sine qua non: que, sendo a língua um instrumento de comunicação, terá de (em maior ou menor grau) ser comum a todos os que a falam, já que de outro modo a concreção da possibilidade de comunicar ficaria liminarmente inviabilizada. E se o emprego criterioso da palavra é condição incontornável do rigor, imprescindível se torna que o jornalista seja detentor de um profundo conhecimento do idioma e da gramática, bem como das subtilezas da sua utilização.

Porém, mais importante do que o vocabulário disponível, e Tusón (1989, p. 34) afirma-o taxativamente, é ser «Una lengua su organización $»^{16}$ (a arquitectura oracional; o sistema de referências interoracionais; a morfologia e o significado dos tempos verbais; a correlação temporal), pois que «Todo ello compone una parte importante de la estructura formal de una lengua, que es precisamente lo que habrá de descubrir quien consiga tener su pericia». Portanto, acima de tudo é no controlo das suas estruturas gramaticais que o domínio de uma língua se manifesta ${ }^{17}$. E é consabido como a deficiente estruturação da frase torna a leitura difícil e, não raro, redunda mesmo na sua ininteligibilidade.

16. O apego deste autor à gramática e a demonstração inequívoca do lugar que lhe concede estão perfeitamente consubstanciados na seguinte asserção (ibid., p. 73): «(...) ser hombre -lo sabemos más que bien, hoy día- es ser grammaticus antes que faber.» 17. É claro que, não menos obnóxios da cabal intelecção do texto, são, quer a actual tendência da linguagem informativa para prolongar a oração à base da junção de complementos - quando, como se sabe, as frases devem, além de curtas, corresponder cada uma a uma informação e cada informação exprimir só uma ideia (fórmula ideal) - quer o uso indiscriminado de termos técnicos, estrangeirismos evitáveis, clichés, siglas impenetráveis e outras 'adiposidades' que, para além de tornarem o texto deselegante, porque inçado de impropriedades vocabulares, provocam no leitor um efeito desmotivador. 
Analisar e reflectir os resultados, que não atingiram a barreira psicológica dos dez deputados, é agora fundamental. [...] os mais qualificados políticos e profissionais para servirem o País, seja como acessores, chefes de gabinete, ministros ou secretários de Estado.

O Primeiro de Janeiro, 14/6/2004, Editorial, p. 2, NM.

Irascível e mordaz, o ambiente almofadado dos Gabinetes da política não servem para lhe tolher estas marcas.

Expresso, 10/6/2004, p. 4, RPL.

Este é, no entanto, apenas um dos problemas que está a assombrar a segurança alimentar durante o Euro. [...]

Segundo o EXPRESSO apurou, a Inspecção-Geral das Actividades Económicas (IGAE) começou esta semana a credenciar os seus inspectores para puderem entrar nos estádios do Euro.

Expresso, 10/6/2004, p. 12, GR.

Os anos passam, mas o debate nas campanhas europeias não são assim tão diferentes.

Diário de Notícias, 7/6/2004, p. 10, NS.

Alberto Torres gracejou que nas novas instalações do comando de Vila Real só caberão de pé, descuidados de não baterem com a cabeça no tecto, agentes que não seja muito altos.

Jornal de Notícias, 15/6/2004, p. 15, JAS.

A coexistência de ambas as entidades, concorrentes entre si, apesar de terem até participações cruzadas, no que pode ser o futuro consórcio, será certamente um assunto de discussão, inclusive porque a relação de ambos os grupos financeiros com os respectivos grupos industriais associados são bastante fortes e não se restringem a este negócio da Galp.

Diário Económico, 2/6/2004, p. 3, FP.

SAÚDE $\triangle$ Unidades de Coimbra e Aveiro com planos de emergência $\triangleright$ Meios humanos duplicam nos dias dos jogos nos serviços de Urgência.

Jornal de Notícias, 15/6/2004, p. 38, JPC/JA. 
No PS, há quem gostasse de ver este independente que foi ministro das Finanças na campanha presidencial.

Diário de Notícias, 7/6/2004, p. 6, MS.

A vítima é apresentada pelo site como sendo «o judeu americano, Robert Jacob, que trabalhava para a sociedade de espionagem Vinnell», reivindicando a sua morte em nome da secção saudita da Al-Qaeda.

Diário de Notícias, 14/6/2004, p. 25, s. a.

A questão 'técnica' é simples: a UEFA não permite a entrada de jornalistas nos estádios que não estejam devidamente credenciados. Mais, precisará de saber quais, quantos e ao que vão.

Jornal de Notícias, 6/6/2004, DESPORTO, p. 2, JLC.

Muito provavelmente a pior campanha publicitária que pariu o Euro. E não deve ter sido barata.

Diário de Notícias, 4/6/2004, DNa, p. 9, CQ.

O desfile de nomes de jogadores que interessam ao Chelsea na imprensa tem os dias contados.

Diário de Notícias, 31/5/2004, p. 31, APP.

Mais de 34 mil funcionários públicos passaram à reforma só no ano passado, elevando o contingente de pensionistas para 355 mil. E, pela primeira vez desde 1995, o número de trabalhadores que saiu da Função Pública foi inferior ao dos que entraram. A redução foi de 4716 funcionários.

«Aposentações no Estado cresceram 50\% em 2003», Diário de Notícias, 11/6/2004, dn Negócios, p. 1.

Como a entrada de novos funcionários foi inferior ao nível de aposentações, o emprego total na administração pública sofreu uma redução de 4716 funcionários. No ano passado ingressaram nos quadros 29351 novos funcionários (menos 1\% do quem 2002) e saíram 34 067, o que equivale à primeira quebra de emprego no sector desde 1995.

Diário de Notícias, 11/6/2004, dn Negócios, p. 8, CA. 
Aliás, a candente questão da linguagem - saber a quem deve competir a sua escolha (se ao público, se ao medium) e as repercussões que ela tem nos leitores - foi já disseccionada por Núñez Ladevéze (1979, p. 125) que, ao equacionar as hipóteses em presença (e citando Raymond Williams, 1971), começa por introduzir uma perspectiva que é, afinal, uma dicotomia antinómica: «¿Hay que dejar que los medios elijan espontáneamente su lenguaje según los dictados del público? ¿No sería más conveniente tratar de imponer al público un lenguaje (consistente), para formarlo y educarlo?», para, prosseguindo na senda da almejada resposta, avançar (ibid., p. 126) com novo testemunho (Valbuena, 1976): «Los medios tienen que satisfacer a los públicos, y su lenguaje lo impone el público, (...)».

Postura que colide com o preconizado por Luka Brajnovic (1991, p. 123), para quem a informação «(...) tiende siempre a ampliar los horizontes del saber participando así activamente en el mejoramiento humano», até porque, ainda segundo o autor (ibid., p. 114), o fim último da informação, é «(...) el enriquecimiento cultural e intelectual, teórico y práctico del hombre y de toda la sociedad», ao que Hernández Gil ${ }^{18}$ acrescenta «(...) conseguir elevar la recepción de la cultura, lo que abre un atrayente proceso de transformación social». Afirmações que só permitem uma leitura: não é introduzindo nos media as limitações culturais de que padece o receptor que se resolve o problema.

Daí que, voltando a R. Williams, e aceite o primado da sua formulação inicial, não se esteja, a nosso ver, a contribuir para a elevação do nível cultural desse mesmo público, na medida em que, ficando as suas exigências pelo mais lhano, isso só pode ter como corolário não ser alcançada a função formativa. E quanto ao argumento de que como os media têm de satisfazer os públicos deverão, para irem ao encontro das solicitações destes, usar a sua linguagem, este peca, em nossa opinião, por capcioso, porquanto há que ter também em consideração o reverso da moeda: se é um facto que têm de satisfazer os públicos, não menos irrefragável ver- 
dade é que, tal como Valbuena ${ }^{19}$ assinala: «(...) pero a la vez conforman el público, e imponen al público su lenguaje», o que, quanto a nós, deveria ser aproveitado pelos media para, tendente à consecução deste desiderato, a aprimorarem. Até porque, contribuir para o enriquecimento cultural dos seus leitores é uma «obrigação moral» do profissional da informação ${ }^{20}$, obrigação reforçada ainda por, dado o estatuto que lhes é hodiernamente outorgado, os media (e a imprensa em particular) terem, no que ao uso da linguagem concerne, responsabilidades acrescidas, e se tanto podem ser um profícuo contributo para a sua dignificação/elevação, também podem - se, por incúria, persistirem exemplos do cariz dos aqui coligidos - contribuir para a proliferação do que João de Melo ${ }^{21}$ apoda de «epidemia de labregos lingüísticos», porque há erros que, de tão repetidos, acabam por se converter em «norma».

Daí a pertinência do alerta lançado por Edite Estrela e Pinto-Correia (1994, p. 23), que - depois de frisarem o imperativo de as frases deverem ser bem construídas e claras, de o discurso dever ser fluente e eficaz para a mensagem ser entendida e de o jornalismo não ser, apenas, um veículo de informação, mas, também, fonte de conhecimento e cultura - preconizam: «Tendo em atenção - outro aspecto, não menos importante - que, em matéria de linguagem, e não só, o público tende a moldar-se à imagem e semelhança de quem lhe leva a informação».

E isto, para o bem e para o mal, tem tudo a ver com o perfil do profissional da informação e a sua relação com a língua.

O texto, que surge em resposta a uma consulta promovida pelo secretário de Estado das Comunidades, José Cesário, ao CCP sobre a matéria, denuncia a «decadencia» das associações portuguesas no estrangeiro.

Jornal de Notícias, 24/6/2004, p. 7, s. a.

19. Citado por Núñez Ladevéze (1979, p. 126).

20. Ou, como discreteando acerca da função que lhe compete, sublinha Luka Brajnovic (ibid., p. 161): «En el fondo se trata de una obligación moral del informador que ni es ni representa poder alguno, [...]. Su función es de servidor que pone - eso sí - toda su capacidad y todas las cualidades y posibilidades de un experto inteligente y honrado al servicio de los demás.»

21. In Notícias Magazine, s/d, p. 6. 
O veleiro STEF era interceptado na Ilha das Flores, nos Açores, estavam 812 quilos de cocaina.

Jornal de Notícias, 24/6/2004, p. 13, VP.

O director de relações culturais do Ministério da Educação iraquiano morreu ontem assassinado em Bagdad, o segundo alto funcionário governamental a morrer violentamente em 24 horas.

Diário de Notícias, 14/6/2004, p. 25, AR.

O PS conseguiu ontem a sua primeira vitória contra o centro-direita coligado na história da democracia portuguesa.

Diário de Notícias, 14/6/2004, p. 20, s. a.

Rosa Barbosa não se apercebeu dos tiros, porque ouve mal, nem viu nada, porque o presumível homicida já se tinha posto em fuga, quando saiu à rua, apesar da vítima ter caído prostrada, a dois passos da porta da casa onde mora, na Rua António José de Almeida.

Jornal de Notícias, 15/6/2004, p. 40, JCM.

Não é assim pelo facto de os prédios não estarem avaliados de acordo com as novas regras que foi retardada a liquidação do IMI, sem prejuízo de quando se realizar a avaliação se proceder à correcção da respectiva mesma.

Diário Económico, 11/6/2004, p. 13, s. a.

O FC Porto-Futebol, SAD acordou com o Chelsea o estabelecimento de uma parceria de cooperação com o clube inglês por cinco anos, com exclusividade para o mercado português, no que respeita à detecção, (...).

Diário Económico, 2/6/2004, p. 36, SSP.

Apesar da extensa lista de deficiências, porém, o grupo de missão garante encontrar nestes projectos «uma qualidade pedagógica bastante superior» à dos que foram apreciados em 2002.

Diário de Notícias, 7/6/2004, p. 22, JPO. 
Quanto a Ralf Shumacher, teve de contentar-se com a merecida segunda posição, já que aspirava logicamente à vitória, depois de ter alcançado a «pole position».

O Primeiro de Janeiro, 14/6/2004, DESPORTO, p. VII, s. a.

(...) Ataide das Neves desmentiu também Adelino Salvado e garantiu que foi contactado pelo director nacional, antes da demissão de Artur Oliveira, e não por causa da prisão dos seus familiares.

Jornal de Notícias, 9/6/2004, p. 10, TL.

É impossível ter todas as Viaturas Médicas de Emergência e Reanimação (VMER) do Instituto Nacional de Emergência Médica (INEM) a funcionar em permanência por falta de profissionais especializados.

Jornal de Notícias, 24/6/2004, p. 8, IC.

Ao fazê-lo, Teresa Gouveia esvaziou a intenção do BE, ao convocar o debate de urgência, de confrontar o Governo a tomar uma decisão sobre a consulta popular. (...)

Indiferentes à polémica sobre a pergunta, os socialistas já definiram, a priori, a sua posição. «O PS é o partido dos dois sim's: sim ao referendo $(. .$.$) ».$

Jornal de Notícias, 24/6/2004, p. 14, AI.

Allawi, antigo militante do Baas que conspirou contra Saddam Hussein no exílio, não perdeu tempo a responder: (...).

Jornal de Notícias, 24/6/2004, p. 22, JMA.

Em conclusão: sendo várias e de diversa índole as ilações a retirar do atrás exposto, globalmente considerados os vectores subjacentes à disquisição a que procedemos, uma emerge e, de tão flagrante, se impõe de imediato: a premente acuidade de a revisão readquirir a importância de que já desfrutou. E se esta é exógena aos profissionais da informação, outras há que lhes devem ser intrínsecas (e ao seu perfil e relacionamento com a língua): em particular a necessidade de maior cuidado aquando da redacção dos textos; ao que acresce, no caso dos mais jovens, o imperativo de 
especial empenhamento tendente à consecução de mais esmero na construção frásica - o que passa pelo incontornável rigor na distribuição dos complementos pela oração - e a observância de uma criteriosa selecção vocabular. Porém, no global, a relação destes profissionais com a língua apresenta ainda outros pontos de fricção - em que pontificam as concordâncias, as construções anfibológicas, as regências verbais e nominais - que temos dificuldade em compreender (porque perfeitamente identificados e constituídos em áreas críticas) e cuja «perpetuaçao» só poderá ser encarada como apodixe de, ao arrepio de tudo o preconizado, esta linguagem continuar a não ser alvo do merecido cuidado.

O que emerge em toda a sua pregnância confrontando os exemplos aduzidos com uma visita aos «clássicos», para os quais constitui preocupação maior o que se passa neste âmbito: de Dovifat (1959, p. 125), que postula, «El lenguaje de la noticia requiere tres cosas: concisión, claridad y una construcción que capte la atención», a Vivaldi (1973, p. 29), que refere «La claridad es la condición primera de la prosa periodística. En el periódico se escribe -ha de escribirse- para que nos entienda todo el mundo: el docto y el menos docto, (...)», passando por Luka Brajnovic (1991, p. 84), que assevera: «En el caso del Periodismo su lenguaje debe ser claro, conciso y sencillo, lo que no quiere decir vulgar (...)», a unanimidade é total. Perante tão óbvia e inequívoca convergência de abalizadas opiniões dos proficientes estudiosos citados - em que a clareza e a correcção emergem e se impõem como condição sine qua non da inteligibilidade do texto - cremos por demais evidente ser absolutamente improtelável pôr termo ao statu quo, porque, a persistir, a conflituosa relação de determinadas franjas de jornalistas com a linguagem conduzirá, inelutavelmente, a uma situação como a que Richaudeau (1984, p. 7) prevê quando, equacionando esta questão, assevera: «Poco importa cuanto podamos pensar o cuanto deseemos transmitir al "otro" si el mensaje no "pasa", si no es percibido por ese otro, o si le llega deformado, desnaturalizado. ¡Y con cuanta frecuencia suele ocurrir tal cosa...!»

Razão por que, mesmo tidas em consideração as limitações (de tempo e não só) em que um discurso como este é produzido, 
e que não raro poderão obstar à concreção da almejada correcção (inclusive à consecução de construções imbuídas do text-appeal susceptível de cativar o leitor), não poderíamos eximir-nos de fazer os reparos aqui expressos - não obstante cônscios de estes não serem bem aceites pelos seus destinatários -, reparos que, não se pretendendo um libelo acusatório contra ninguém, se limitam a assinalar um deplorável flagelo que urge combater/erradicar, e, concomitantemente, conseguir que a preocupação de rigor passe a ser o arquétipo norteador. 


\section{REFERÊNCIAS BIBLIOGRÁFICAS}

\section{CIÊNCIAS DA INFORMAÇÃO}

Brajnovic, Luka. (1991): El Ambito Científico de la Información. Pamplona, Ediciones Universidad de Navarra, S. A. (EUNSA), $2^{\mathrm{a}} \mathrm{ed}$.

Diezhandino, María Pilar. (1994): El Quehacer Informativo. El "arte de escribir" un texto periodístico. Bilbao, Servicio Editorial de la Universidad del País Vasco.

Dovifat, Emil. (1959/60): Periodismo. (I/II). México, UTEHA.

Estrela, Edite e Pinto-Correia, J. David. (1994): Guia Essencial da Língua Portuguesa para a Comunicação Social. Lisboa, Editorial Notícias, $3^{\mathrm{a}}$ ed.

Hernando, Bernardino M. (1990): Lenguaje de la Prensa. Madrid, EUDEMA (Ediciones de la Universidad Complutense, S. A.).

LÁzARO CARRETER, Fernando et alii. (1977): «El lenguaje periodístico, entre el literario, el administrativo y el vulgar», in Lenguaje en periodismo escrito. Madrid, Fundación Juan March.

MarTín Vivaldi, Gonzalo. (1990): Curso de Redacción. Teoría y práctica de la composición y del estilo. Madrid, Paraninfo, $21^{\text {a }}$ edición corregida.

Martínez Albertos, José Luis. (1983): Curso General de Redacción Periodística. Barcelona, Editorial Mitre.

Martínez Albertos, José Luis. (1989): El lenguaje periodístico. Madrid, Paraninfo.

Mesquita, Mário. (2003): O Quarto Equívoco - O Poder dos Media na Sociedade Contemporânea. Coimbra, Ed. MinervaCoimbra.

NúÑez LadeVÉze, Luis. (1979): El lenguaje de los «media». Introducción a una teoría de la actividad periodística. Madrid, Ediciones Pirámide.

NúÑEz LadeVÉze, Luis. (1993): Teoría y Práctica de la Construcción 
del Texto. Barcelona, Editorial Ariel, S. A.

Raimundo, Orlando. (1994): A Linguagem dos Jornalistas. Manual de Escrita Jornalística. Lisboa, Acontecimento, Estudos e Edições, Lda., $2^{\text {a }}$ ed. rev.

Richaudeau, François. (1984): Los Secretos de la Comunicación Eficaz. Bilbao, Ed. Mensajero.

Saraiva, José António. (2003): Confissões de um Director de Jornal. Lisboa, Public. Dom Quixote.

Trigo, Salvato. (1987): «Palavras Prévias», in AA. VV., Jornalismo e Literatura. Actas do II Encontro Afro-Luso-Brasileiro. Lisboa, Ed. Vega.

Tusón, Jesús. (1995): El lujo del lenguage. Barcelona, Paidós, $3^{a}$ ed.

VV.AA. (1987): Jornalismo e Literatura. Actas do II Encontro LusoAfro-Brasileiro. Lisboa, Ed. Vega.

\section{CORRECÇÃO LINGÜÍSTICA}

Carmo Vaz. (1992): Linguística para Todos. Lisboa, Círculo de Leitores.

Cunha, Celso e Lindley Cintra, Luís Filipe. (1986): Nova Gramática do Português Contemporâneo. Lisboa, Edições João Sá da Costa, $2^{a}$ ed.

Estrela, Edite. (1985): Bem Dizer, Bem Escrever. Lisboa, Ed. Notícias.

Fernandes, Francisco. (1980): Dicionário de Regimes de Substantivos e Adjetivos. Porto Alegre, Editora Globo, $17^{\mathrm{a}} \mathrm{ed}$.

Machado, José Pedro (coord.). (1982): Dicionário de Dúvidas e Dificuldades da Lingua Portuguesa. Lisboa, Sociedade de Língua Portuguesa, vol. I.

Nogueira, Rodrigo de Sá. (1969): Dicionário de Erros e Problemas de Linguagem. Lisboa, Livraria Clássica Editora. 
Peres, João Andrade e MóiA, Telmo. (1995): Áreas Críticas da Lingua Portuguesa. Lisboa, Editorial Caminho.

Rodrigues Lapa, M. (1979): Estilística da Lingua Portuguesa. Coimbra, Coimbra Editora, Lda., 10 ${ }^{\mathrm{a}}$ ed., rev. act.

Said Ali, M. (1966): Dificuldades da Lingua Portuguesa. Rio de Janeiro, Liv. Académica, $6^{\mathrm{a}}$ ed. 